\title{
Synthesis, Structural Characterization, and Catalytic Properties of Tungsten-Exchanged H-ZSM5 ${ }^{\dagger}$
}

\author{
Weiping Ding, ${ }^{\ddagger}$ George D. Meitzner, ${ }^{\S}$ David O. Marler," and Enrique Iglesia* \\ Materials Sciences Division, E. O. Lawrence Berkeley National Laboratory, and Department of Chemical \\ Engineering, University of California at Berkeley, Berkeley, California 94720
}

Received: September 21, 2000; In Final Form: January 18, 2001

\begin{abstract}
W-exchanged $\mathrm{H}-\mathrm{ZSM} 5$ was prepared by sublimation of $\mathrm{WCl}_{6}$ at $673 \mathrm{~K}$ followed by hydrolysis of exchanged $\mathrm{WCl}_{x}$ species at $523 \mathrm{~K} . \mathrm{D}_{2}$ exchange with residual $\mathrm{OH}$ groups showed that each $\mathrm{W}$ initially replaced about two zeolitic protons for W/Al ratios of 0.29 and 0.44 , consistent with the formation of $\left(\mathrm{WO}_{2}\right)^{2+}$ containing $\mathrm{W}^{6+}$ species bridging two cation exchange sites. As temperatures reached $\sim 973 \mathrm{~K}$ during $\mathrm{D}_{2}-\mathrm{OH}$ exchange, these species reduced to $\left(\mathrm{WO}_{2}\right)^{+}$with the concurrent formation of one OD group. $\mathrm{CH}_{4}$ conversion turnover rates (per $\mathrm{W}$ ) and $\mathrm{C}_{2}-\mathrm{C}_{12}$ selectivities are very similar to those observed on a Mo/H-ZSM5 sample with similar cation exchange level. As in the case of Mo/H-ZSM5, $\mathrm{WO}_{x} / \mathrm{H}-\mathrm{ZSM} 5$ precursors are initially inactive in $\mathrm{CH}_{4}$ reactions, but they activate during induction with the concurrent evolution of $\mathrm{CO}, \mathrm{H}_{2} \mathrm{O}$, and an excess amount of $\mathrm{H}_{2}$. The reduction and carburization processes occurring during $\mathrm{CH}_{4}$ reactions and the structure of the exchanged $\mathrm{WO}_{x}$ precursors was probed using in situ X-ray absorption spectroscopy (XAS). XAS studies confirmed the isolated initial nature of the exchanged $\mathrm{WO}_{x}$ precursors after hydrolysis and dehydration and the formation of $\mathrm{WC}_{x}$ clusters $\sim 0.6 \mathrm{~nm}$ in diameter during $\mathrm{CH}_{4}$ reactions at $973 \mathrm{~K}$. The structural and catalytic resemblance between W- and Mo-exchanged H-ZSM5 is not unexpected, in view of chemical similarities between oxides or carbides of Mo and $\mathrm{W}$. The synthesis of exchanged $\mathrm{WO}_{x}$ precursors and their subsequent carburization during $\mathrm{CH}_{4}$ reactions, however, are more difficult than the corresponding processes for the $\mathrm{MoO}_{x}$ counterparts. This may account for previous reports of lower $\mathrm{CH}_{4}$ reaction rates and aromatics selectivities on W/H-ZSM5 compared with those observed on Mo/H-ZSM5 and with those reported here for rigorously exchanged W/H-ZSM5.
\end{abstract}

\section{Introduction}

Transition metal ions (e.g., Mo, W, V, Fe, Cr) loaded onto several zeolites (HZSM-5, HZSM-11, HZSM-8, H-beta, HMCM41, HMCM-49, HMCM-22, HY, and H-mordenite) ${ }^{1-9}$ have been widely studied as catalysts for methane conversion reactions, after initial reports of selective benzene formation from methane on $\mathrm{Mo} / \mathrm{H}-\mathrm{ZSM} 5,{ }^{2}$ often without direct structural evidence for the presence of cations at exchange sites after synthesis or during reaction. Mo/H-ZSM5 remains the best reported catalyst for this reaction in terms of reaction rate and benzene selectivity. Several synthetic routes and zeolite $\mathrm{Si} / \mathrm{Al}$ ratios have led to similar catalytic performance for Mo/H-ZSM5 catalysts, in many cases because many of them lead to nearequilibrium $\mathrm{CH}_{4}$ conversion to benzene.

Lunsford et al. showed that $\mathrm{Mo}_{2} \mathrm{C}$ is present in Mo/H-ZSM5 catalysts after $\mathrm{CH}_{4}$ reactions using X-ray photoelectron spectroscopy (XPS) after reaction. They detected carbidic carbon on $\mathrm{Mo} / \mathrm{H}-\mathrm{ZSM} 5$ and showed that $\mathrm{MoO}_{x}$ species reduce almost to $\mathrm{Mo}^{0}$ during reaction. ${ }^{10}$ Their angle-resolved XPS measurements led them to conclude that $\mathrm{Mo}_{2} \mathrm{C}$ clusters at external zeolite

\footnotetext{
$\doteqdot$ Part of the special issue "John T. Yates, Jr. Festschrift".

* To whom correspondence should be addressed. E-mail address: Iglesia@cchem.berkeley.edu.

$\doteqdot$ Permanent address: Department of Chemistry, Nanjing University, Nanjing 210093, China.

$\S$ Current address: Edge Analytical Inc., 2126 Allen Blvd. \#3, Middleton WI 53562

"Current address: ExxonMobil Process Research Laboratory, Baton Rouge, LA.
}

SCHEME 1: Solid Exchange of H-ZSM-5 with $\mathrm{WCl}_{6}$ and Hydrolysis of Exchanged $\mathrm{WCl}_{x}$ to the $\mathrm{WO}_{x}$ Group
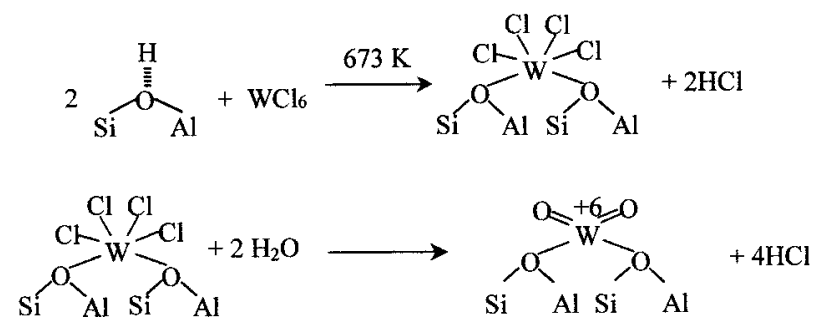

surfaces were involved in the rate-determining initial formation of $\mathrm{C}_{2} \mathrm{H}_{4}$. Solymosi et al. also concluded that $\mathrm{Mo}_{2} \mathrm{C}$ clusters provide the active sites for the initial formation of $\mathrm{C}_{2} \mathrm{H}_{4}$, which then convert on Bronsted acid sites to benzene, naphthalene, and larger polynuclear aromatics. ${ }^{11-14}$ The catalyst operates as a bifunctional catalyst for methane conversion to aromatics. ${ }^{5}$ The similarities between $\mathrm{Mo}$ and $\mathrm{W}$, and between $\mathrm{Mo}_{2} \mathrm{C}$ and $\mathrm{WC}$, in their catalytic properties suggest that W/H-ZSM5 materials should resemble Mo/H-ZSM5 in their ability to activate $\mathrm{CH}_{4}{ }^{15}$ Yet, recent studies have concluded that $\mathrm{Mo} / \mathrm{H}-$ ZSM5 catalysts are significantly more active and selective than W/H-ZSM5 in methane conversion reactions. ${ }^{3,16}$

We have recently shown that $\mathrm{MoO}_{3}$ species migrate into zeolite channels and exchange with $\mathrm{OH}$ groups in $\mathrm{H}-\mathrm{ZSM} 5$ to form $\left(\mathrm{Mo}_{2} \mathrm{O}_{5}\right)^{2+}$ dimers anchored at two cation exchange sites (Scheme 1) when $\mathrm{MoO}_{3} / \mathrm{H}-\mathrm{ZSM} 5$ physical mixtures are heated in dry air at $773-973 \mathrm{~K} .{ }^{17,18}$ These results confirmed the highly dispersed and unreduced nature of these $\mathrm{MoO}_{x}$ catalyst precur- 
sors. The inferior catalytic properties reported for W/H-ZSM5 may reflect a low initial dispersion of $\mathrm{WO}_{x}$ precursors, which precludes the presence of highly dispersed active species within shape-selective zeolite channels. Methane would then rapidly deactivate these external sites because large polynuclear hydrocarbons form readily on the surface of carbide clusters at high temperatures. ${ }^{12}$ Here, we report the synthesis, characterization, and catalytic properties of W-exchanged H-ZSM5. We show that $\mathrm{CH}_{4}$ conversion rates and selectivities resemble those observed on Mo/H-ZSM5. In this study, W/H-ZSM5 samples were prepared by $\mathrm{WCl}_{6}$ sublimation methods, which led to quantitative exchange of $\mathrm{W}^{6+}$ species. The catalytic properties of both Mo/H-ZSM5 and W/H-ZSM5 were compared at conditions away from equilibrium, in order to discern accurately the respective catalytic properties of these samples.

\section{Experimental Section}

2.1. Synthesis of W-Exchanged H-ZSM5. Our attempts to prepare $\mathrm{W}$-exchanged $\mathrm{H}$-ZSM5 by aqueous or solid-state exchange using several $\mathrm{W}^{6+}$ precursors $\left(\mathrm{WO}_{3}, \mathrm{WO}_{2}, \mathrm{H}_{2} \mathrm{WO}_{4}\right.$, and $\left.\mathrm{Na}_{2} \mathrm{WO}_{4}\right)$ followed by oxidative $\left(\mathrm{O}_{2}+\mathrm{He}\right)$ or reductive $\left(\mathrm{H}_{2}+\mathrm{He}\right)$ environments up to $973 \mathrm{~K}$ failed to replace a significant fraction of the $\mathrm{OH}$ groups initially present in the $\mathrm{H}-\mathrm{ZSM} 5$ sample. The isotopic exchange of $\mathrm{D}_{2}$ with these $\mathrm{OH}$ led to $\mathrm{OH}$ surface densities (measured from the amounts of HD and $\mathrm{H}_{2}$ evolved) indistinguishable from those in the starting $\mathrm{H}-Z \mathrm{SM}$ 5. It appears that, in contrast with $\mathrm{MoO}_{3},{ }^{17} \mathrm{~W}^{6+}$ oxo species in $\mathrm{WO}_{3}$ crystallites become mobile only at very high temperatures, at which the zeolite crystal structure is destroyed.

Impregnation of H-ZSM5 with aqueous ammonium metatungstate followed by treatment in air at $773 \mathrm{~K}$, a procedure adopted in previously reported W/H-ZSM5 samples, 3,16 also did not lead to detectable replacement of OH groups in H-ZSM5 by $\mathrm{W}^{6+}$ cations. In general, the exchange of trivalent and higher cations from solution into ZSM5 channels tends to be impaired by the large hydration coordination sphere required to stabilize such cations in aqueous environments. Invariably, alternate methods that avoid solvation must be used for the successful exchange of high-valent cations onto medium-pore zeolites. In the present study, sublimation of $\mathrm{WCl}_{6}$ was successfully used, by analogy with recent reports of the synthesis of exchanged $\mathrm{Fe}^{3+}$ in $\mathrm{H}-\mathrm{ZSM} 5 .{ }^{19}$

Anhydrous $\mathrm{WCl}_{6}$ crystals melt at $548 \mathrm{~K}$ and boil at $620 \mathrm{~K}$; $\mathrm{WCl}_{6}$ is readily hydrolyzed by contact with water to form $\mathrm{HCl}$ and tungsten oxides and oxihydroxides. ${ }^{20}$ Therefore, $\mathrm{WCl}_{6}$ monomers should be able to migrate, via gas phase or surface diffusion, into $\mathrm{H}-\mathrm{ZSM} 5$ channels and react with $\mathrm{OH}$ groups to also form $\mathrm{HCl}$ and $\mathrm{W}(\mathrm{VI})$ species anchored as $\left(\mathrm{WCl}_{5}\right)^{+}$or $\left(\mathrm{WCl}_{4}\right)^{2+}$ species, replacing one or two protons, respectively.

Figure 1 shows the glass ampule system used for the synthesis of exchanged $\mathrm{W}(\mathrm{VI})$ species using physical mixtures of anhydrous $\mathrm{WCl}_{6}$ and dehydrated $\mathrm{H}-\mathrm{ZSM} 5$. Before mixing, $\mathrm{WCl}_{6}$ (Aldrich, 99.9+\%) was placed in tube a under dry $\mathrm{N}_{2}$ and the valve 1 was closed. H-ZSM5 (Zeolyst International, $\mathrm{Si} / \mathrm{Al}=$ 15) was placed in tube $b$, and both tubes were evacuated to $\sim 0.133 \mathrm{~Pa}$ with tube $\mathrm{b}$ kept at $573 \mathrm{~K}$ for $3 \mathrm{~h}$. The amount of $\mathrm{WCl}_{6}$ required to give W/Al ratios of 0.29 and 0.44 (4 and 6 wt $\%$, respectively) was then mixed with the dry H-ZSM5 by opening valve 1 and rotating tube a around the joint in order to move the $\mathrm{WCl}_{6}$ powder from tube a to tube $\mathrm{b}$. Then, the tube b was sealed by flame at point c. The sealed ampule, after 0.2 $\mathrm{h}$ ultrasonic agitation for mixing, was heated to $673 \mathrm{~K}$ and kept at this temperature for $4 \mathrm{~h}$. The sample was discharged by

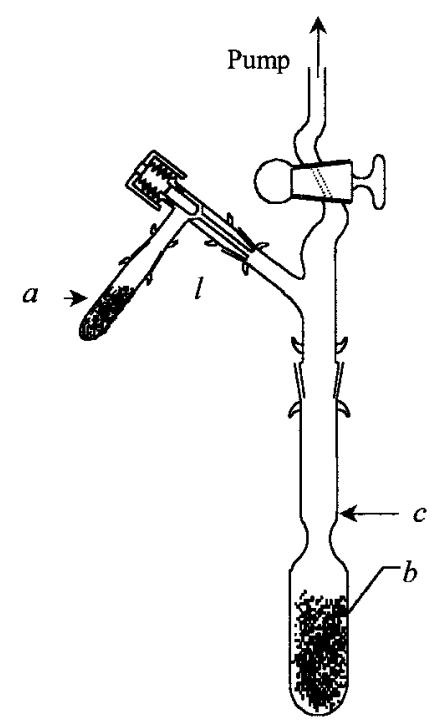

Figure 1. Glass ampule used for exchange of $\mathrm{WCl}_{6}$ with H-ZSM-5.

breaking the ampule in a $\mathrm{N}_{2}$ atmosphere and then transferring the solid into a quartz cell. Within this cell, the samples were treated by the procedure described below before all characterization and catalytic measurements. The samples were heated to $523 \mathrm{~K}$ at $10 \mathrm{~K} / \mathrm{min}$ in $20 \% \mathrm{O}_{2} / 0.5 \% \mathrm{H}_{2} \mathrm{O} / \mathrm{He}\left(100 \mathrm{~cm}^{3} / \mathrm{min}\right)$ and held at this temperature for $0.5 \mathrm{~h}$; the temperature was then increased to $973 \mathrm{~K}$ at $10 \mathrm{~K} / \mathrm{min}$ and held for another $0.5 \mathrm{~h}$ in flowing dry $20 \% \mathrm{O}_{2} / \mathrm{He}\left(100 \mathrm{~cm}^{3} / \mathrm{min}\right)$. Water vapor was added during the first stage of this treatment by passing gases through a bubbler containing deionized doubly distilled water. Water vapor was used in order to complete the hydrolysis of anchored $\mathrm{WCl}_{x}$ species, but then it was removed during the latter stages of this treatment in order to prevent dealumination and loss of crystallinity of ZSM-5 at the higher temperatures. The evolution of $\mathrm{HCl}$ was continuously monitored during these treatments by mass spectrometry (Leybold-Inficon, Transpector 1.0) in order to measure the kinetics of hydrolysis of $\mathrm{WCl}_{x} / \mathrm{H}-\mathrm{ZSM} 5$ to form $\mathrm{WO}_{x} / \mathrm{H}-\mathrm{ZSM}$ 5. Two samples, with $\mathrm{W} / \mathrm{Al}_{\mathrm{F}}$ (F: framework) ratios of $0.29(4 \mathrm{wt} \% \mathrm{~W})$ and $0.44(6 \mathrm{wt} \% \mathrm{~W})$, were prepared using this method, and they are denoted as $0.29 \mathrm{~W}$ and $0.44 \mathrm{~W}$, respectively.

2.2. Isotopic Exchange of $D_{2}$ with Zeolite $\mathbf{O H}$ Groups. The isotopic exchange of $\mathrm{D}_{2}$ with zeolite $\mathrm{OH}$ groups was used in order to measure the extent of W(VI) exchange and the number of sites occupied by each W(VI) oxo species after exchange. After synthesis using the method described in the previous section, the samples $(\sim 0.2 \mathrm{~g})$ were placed in a quartz tube and heated to $973 \mathrm{~K}$ at $10 \mathrm{~K} / \mathrm{min}$ in $20 \% \mathrm{O}_{2} / \mathrm{He}\left(100 \mathrm{~cm}^{3} / \mathrm{min}\right.$; Airgas, UHP), held at $973 \mathrm{~K}$ for $0.5 \mathrm{~h}$, and cooled to room temperature in He. Then, a flow of $5 \% \mathrm{D}_{2} / \mathrm{Ar}\left(60 \mathrm{~cm}^{3} / \mathrm{min}\right.$; Matheson, UHP) was passed through the sample bed, while heating it to $973 \mathrm{~K}$ at $10 \mathrm{~K} / \mathrm{min}$ and then holding at this temperature for $0.5 \mathrm{~h}$. The $\mathrm{HD}$ and $\mathrm{H}_{2}$ evolved during $\mathrm{D}_{2}-\mathrm{OH}$ exchange were measured by mass spectrometry (LeyboldInficon, Transpector 1.0). Argon was used as an internal standard in these measurements. These $\mathrm{D}_{2}-\mathrm{OH}$ exchange measurements were followed by the subsequent exchange of $\mathrm{OD}$ with $\mathrm{H}_{2}$ using an identical procedure, but a flow of $5 \% \mathrm{H}_{2} / \mathrm{Ar}$ instead of $5 \%$ $\mathrm{D}_{2} / \mathrm{Ar}$. These $\mathrm{H}_{2}-\mathrm{OD}$ experiments were used to detect any structural transformations, such as reduction or migration, which may have occurred during the initial exposure of the samples to $\mathrm{H}_{2}$-containing streams at $973 \mathrm{~K}$.

2.3. Catalytic Conversion of Methane. Exchanged $\mathrm{WO}_{x} /$ $\mathrm{H}-\mathrm{ZSM} 5$ samples $(0.5 \mathrm{~g})$ prepared by the $\mathrm{WCl}_{6}$ method were 
placed in a quartz tube, heated in $20 \% \mathrm{O}_{2} / \mathrm{He}\left(50 \mathrm{~cm}^{3} / \mathrm{min}\right.$, Airgas, UHP) to $973 \mathrm{~K}$, held at $973 \mathrm{~K}$ for $0.2 \mathrm{~h}$, and flushed with $\mathrm{He}\left(40 \mathrm{~cm}^{3} / \mathrm{min}\right.$, UHP) for $0.3 \mathrm{~h}$. Helium was then replaced with a $50 \% \mathrm{CH}_{4} / \mathrm{Ar}$ reactant mixture $\left(12.5 \mathrm{~cm}^{3} / \mathrm{min}\right.$, Praxair). The concentrations of unreacted methane and reaction products were measured with a Hewlett-Packard 5890 gas chromatograph. A Porapak Q packed column $(3 \mathrm{~mm} \times 2 \mathrm{~m})$ connected to a thermal conductivity detector and a methylsilicone HP-1 capillary column $(0.32 \mathrm{~mm} \times 50 \mathrm{~m})$ connected to a flame-ionization detector (FID) were used to separate and detect all reaction products. The first column was used to measure $\mathrm{H}_{2}, \mathrm{Ar}, \mathrm{CH}_{4}$, $\mathrm{CO}$, and $\mathrm{CO}_{2}$, and the second column to measure $\mathrm{CH}_{4}, \mathrm{C}_{2} \mathrm{H}_{4}$, $\mathrm{C}_{2} \mathrm{H}_{6}$, benzene, toluene, and naphthalene. Small amounts of other hydrocarbons were also detected in the capillary column; these included $\mathrm{C}_{3}, \mathrm{C}_{4}$, and $\mathrm{C}_{5}$ alkanes, xylenes, and methylnaphthalenes. Methane conversion was calculated as the percentage of the entering methane that disappeared during reaction, calculated using Ar as the internal standard. Selectivities are reported on a carbon basis as the percentage of the converted $\mathrm{CH}_{4}$ that appeared as each detected reaction product. The sum of all individual selectivities is generally less than $100 \%$, because products larger than naphthalene do not quantitatively reach the gas chromatograph through the heated transfer lines maintained at $\sim 423 \mathrm{~K}$.

2.4. X-Ray Absorption Measurements. X-Ray absorption spectra were acquired using beamline BL4-1 at the Stanford Synchrotron Radiation Laboratory (SSRL) using a Si(111) twocrystal monochromator. A beam definition slit inside the hutch was set with vertical and horizontal apertures of $0.42 \mathrm{~mm}$ and $12 \mathrm{~mm}$, respectively. The in-situ X-ray absorption cell consists of a thin wall quartz capillary ( $2 \mathrm{~mm}$ diameter; wall thickness $<0.1 \mathrm{~mm}$ ) with flow-through capabilities; its detailed design has been described previously. ${ }^{21,22}$ A hydrolyzed $0.44 \mathrm{~W}$ sample ( $\sim 0.02 \mathrm{~g}$; particle size, $<0.25 \mathrm{~mm}$ ) was charged into this cell. The sample was heated in $20 \% \mathrm{O}_{2} / \mathrm{He}\left(2 \mathrm{~cm}^{3} / \mathrm{min}\right)$ to $973 \mathrm{~K}$ at $10 \mathrm{~K} / \mathrm{min}$, held for $0.5 \mathrm{~h}$, and then cooled to room temperature in He (denoted as dehydrated $0.44 \mathrm{~W}$ ) before X-ray absorption spectra were collected. Then, the sample was heated in $5 \% \mathrm{D}_{2} /$ Ar to $973 \mathrm{~K}$, held for $0.5 \mathrm{~h}$, and cooled to room temperature. Finally, the sample was heated in $2 \mathrm{~cm}^{3} / \mathrm{min} \mathrm{CH}_{4} / \mathrm{Ar}(1 / 1)$ at $10 \mathrm{~K} / \mathrm{min}$ to $973 \mathrm{~K}$, held at this temperature for $1 \mathrm{~h}$, and cooled to room temperature (denoted as carburized $0.44 \mathrm{~W}$ ) and its spectrum recorded in flowing $\mathrm{He}$. The X-ray absorption spectrum of a commercial WC sample (WC, Alfa Chemicals, 99.5\%) was also obtained at room temperature.

The fine structure (EXAFS) in the X-ray absorption spectra was analyzed using WinXas97 (version 2.0) ${ }^{23}$ and FEFF8.0. ${ }^{24}$ The code ATOMS ${ }^{25}$ was used to provide FEFF8.0 simulations with coordination numbers and interatomic distances for compounds with known structures $\left(\mathrm{WO}_{3}, \mathrm{WC}\right)$. The $k^{3}$-weighted fine structure data was Fourier transformed in the range $0.3-$ $1.5 \mathrm{~nm}^{-1}$ and fitted in $R$-space to $0.8 \mathrm{~nm}$, using $\mathrm{WO}_{3}$ and $\mathrm{WC}$ clusters of radius $0.4 \mathrm{~nm}$ as the starting models in the structural refinement of exchanged $\mathrm{WO}_{x} / \mathrm{H}-\mathrm{ZSM} 5$ and carburized $\mathrm{WC}_{x} /$ H-ZSM5, respectively. A multishell fit was used to determine interatomic distances $(R)$, coordination numbers $(\mathrm{CN})$, and Debye-Waller Factors $\left(\Delta \sigma^{2}\right)$.

\section{Results and Discussion}

Figure 2 shows the $\mathrm{HCl}$ evolution rate during treatment of $\mathrm{WCl}_{6}$-exchanged samples in $\mathrm{H}_{2} \mathrm{O} / \mathrm{O}_{2} / \mathrm{He}$. $\mathrm{HCl}$ evolution was detected at room temperature as soon as the gas flow was switched from dry $\mathrm{O}_{2} / \mathrm{He}$ to $\mathrm{H}_{2} \mathrm{O} / \mathrm{O}_{2} / \mathrm{He}$ gas mixtures. These results confirm the rapid hydrolysis of exchanged $\mathrm{WCl}_{x}$ to $\mathrm{WO}_{x}$ species, even at room temperature.

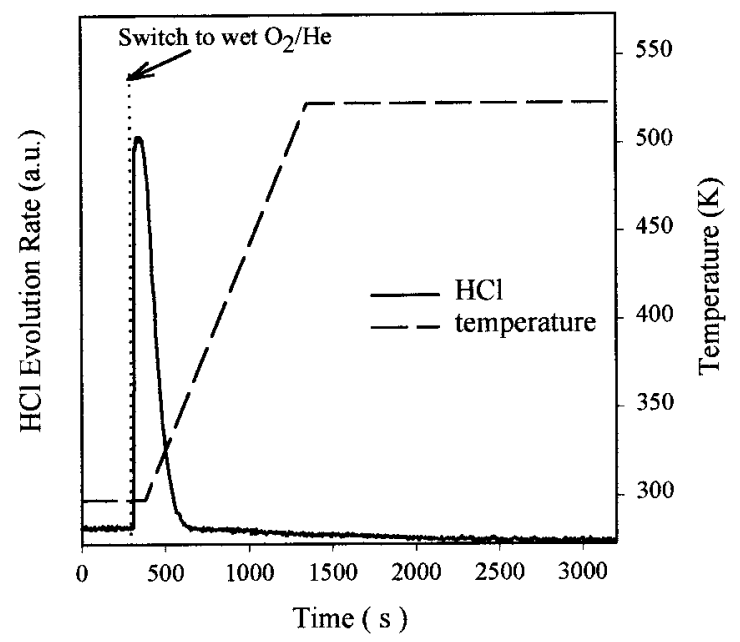

Figure 2. $\mathrm{HCl}$ evolution during treatment of exchanged $\mathrm{WCl}_{x} / \mathrm{H}$ ZSM-5 with $100 \mathrm{~cm}^{3} / \mathrm{min}$ wet $20 \% \mathrm{O}_{2} / \mathrm{He}$.

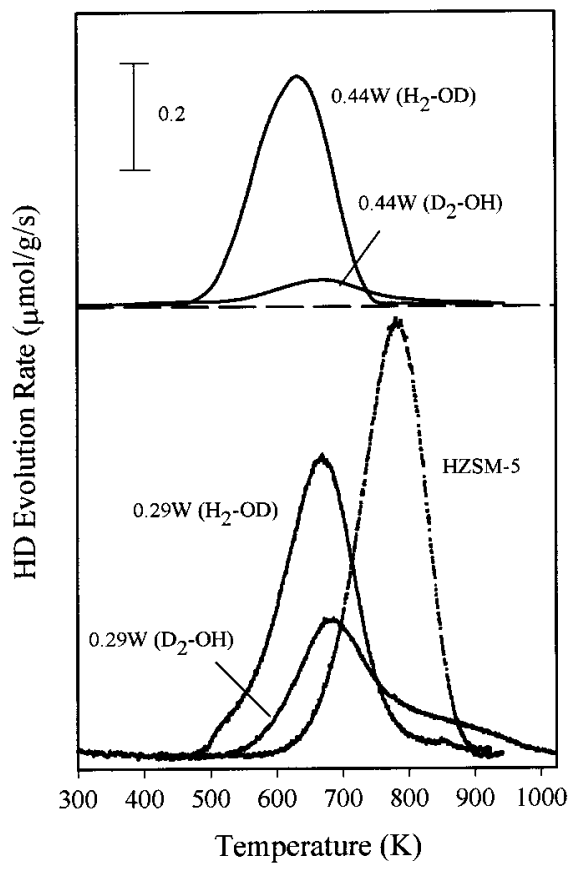

Figure 3. $\mathrm{HD}$ evolution during $\mathrm{D}_{2}-\mathrm{OH}$ exchange $\left(60 \mathrm{~cm}^{3} / \mathrm{min}, 5 \%\right.$ $\left.\mathrm{D}_{2} / \mathrm{Ar}, 10 \mathrm{~K} / \mathrm{min}\right)$ and $\mathrm{H}_{2} \mathrm{OD}\left(60 \mathrm{~cm}^{3} / \mathrm{min}, 5 \% \mathrm{H}_{2} / \mathrm{Ar}, 10 \mathrm{~K} / \mathrm{min}\right)$.

Figure 3 shows the rate of HD evolution during isotopic exchange of $\mathrm{D}_{2}$ with the $\mathrm{OH}$ groups remaining after exchange with $\mathrm{WCl}_{6}$, hydrolysis of the exchanged species and dehydration at $973 \mathrm{~K}$ in $0.29 \mathrm{~W}$ and $0.44 \mathrm{~W}$ samples. HD evolution peaks were observed at $\sim 683 \mathrm{~K}$ and $664 \mathrm{~K}$ for $0.29 \mathrm{~W}$ and $0.44 \mathrm{~W}$, respectively. The shape of the evolution peak is consistent with first-order exchange kinetics, as reported previously for Mo/ H-ZSM5; ${ }^{17,18}$ the peak temperatures were slightly lower than on $\mathrm{H}-\mathrm{ZSM} 5$, but higher than on Mo/H-ZSM5 samples with similar $\mathrm{M} / \mathrm{Al}$ ratios. This suggests that $\left(\mathrm{WO}_{x}\right)^{n+}$ exchanged species catalyze the rate-determining $\mathrm{D}_{2}$ dissociation steps required for exchange, but less effectively than $\left(\mathrm{Mo}_{2} \mathrm{O}_{5}\right)^{2+}$ dimers present in $\mathrm{MoO}_{x} / \mathrm{H}-\mathrm{ZSM} 5$, which decrease the HD evolution peak to $\sim 573 \mathrm{~K} \cdot{ }^{17,18}$ As the W/Al ratio decreases from 0.44 to 0.29 , the HD peak temperature increases slightly from 664 to $683 \mathrm{~K}$ (Figure 3).

The areas of the HD evolution peaks in Figure 3 represent the number of zeolitic $\mathrm{OH}$ remaining after $\mathrm{W}$ exchange. When these data are compared with the initial OH density in H-ZSM5, the average number of protons removed by each $\mathrm{W}^{6+}(\mathrm{H} / \mathrm{W})$ 


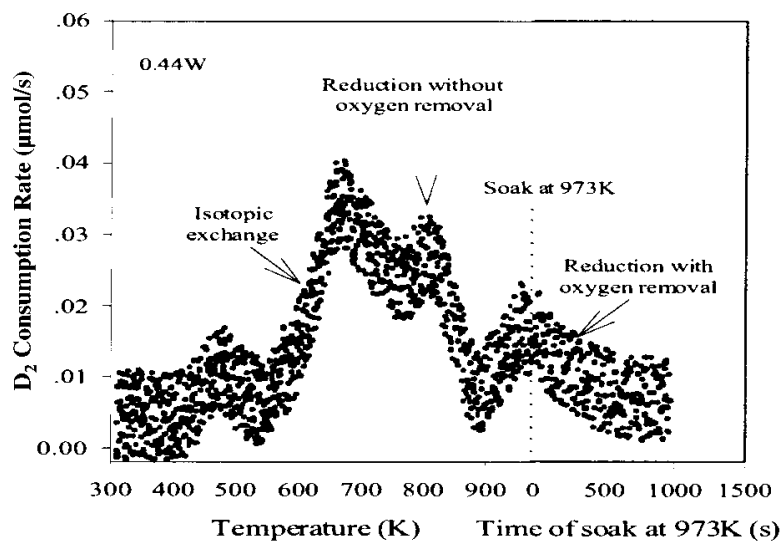

Figure 4. $\mathrm{D}_{2}$ consumption rates during $\mathrm{D}_{2}-\mathrm{OH}$ exchange.

SCHEME 2: Reduction Mechanism of Exchanged $\mathrm{WO}_{x} /$ H-ZSM-5 by $D_{2}$

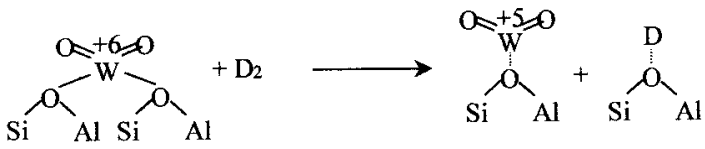

can be estimated. The ratios obtained by this procedure were 2.15 and 1.8 for $0.29 \mathrm{~W}$ and $0.44 \mathrm{~W}$, respectively. The value of $\sim 2$ obtained for both samples suggests that each exchanged $\mathrm{WCl}_{x}$ group replaces two protons in $\mathrm{H}-\mathrm{ZSM} 5$ during the initial exchange. Only $\left(\mathrm{WCl}_{4}\right)^{2+}$ monomers bridging two exchange sites are consistent with this exchange stoichiometry. These monomers then hydrolyze near room temperature to form bridging $\left[\mathrm{W}(\mathrm{OH})_{4}\right]^{2+}$ species, which subsequently dehydrate during thermal treatment at $523 \mathrm{~K}$ by condensation of the $\mathrm{OH}$ groups in $\left[\mathrm{W}(\mathrm{OH})_{4}\right]^{2+}$ to form $\left(\mathrm{WO}_{2}\right)^{2+}$ species bridging two exchange sites (Scheme 1).

The results of a subsequent $\mathrm{H}_{2}-\mathrm{OD}$ exchange carried out immediately after the initial $\mathrm{D}_{2}-\mathrm{OH}$ exchange measurements are also shown in Figure 3. The amount of residual hydroxyl groups increased after the initial $\mathrm{D}_{2} / \mathrm{Ar}$ treatment at $973 \mathrm{~K}$, which leads to partial reduction of $\mathrm{W}(\mathrm{VI})$ with the concurrent evolution of water during $\mathrm{D}_{2}-\mathrm{OH}$. The difference between the $\mathrm{OH}$ density in this reduced sample and in the starting H-ZSM5 corresponds to $0.86 \mathrm{OH} / \mathrm{W}$ for $0.44 \mathrm{~W}$ and $0.79 \mathrm{OH} / \mathrm{W}$ for $0.29 \mathrm{~W}$. In contrast with the exchanged sample before reduction, the structures present after reduction have led to $\mathrm{W}$ species that replace only one proton (Scheme 2). As shown in Scheme 2, the reduction of exchanged W(VI) species leads to the formation of $\mathrm{WO}_{2}{ }^{+}$and one OD group, a process that requires additional $\mathrm{D}_{2}$ molecules to be consumed, beyond those required for $\mathrm{OH}$ exchange. The $\mathrm{D}_{2}$ consumption peaks observed during the first $\mathrm{D}_{2}-\mathrm{OH}$ exchange process confirm this proposal (Figure 4). Three peaks of $\mathrm{D}_{2}$ consumption are detected during $\mathrm{D}_{2} / \mathrm{Ar}$ treatment. For the first peak at $\sim 670 \mathrm{~K}, \mathrm{D}_{2}$ is consumed only as the result of $\mathrm{D}_{2}-\mathrm{OH}$ exchange and it is consistent with the amount of HD concurrently evolved (Figure 3 ). The peak at $\sim 810 \mathrm{~K}$ corresponds to the reduction of $\mathrm{WO}_{2}{ }^{2+}$ to form $\mathrm{WO}_{2}{ }^{+}$ and OD groups; it is not accompanied by the evolution of HD or water. A third $\mathrm{D}_{2}$ consumption peak $(\sim 900 \mathrm{~K})$ coincides with a water evolution peak shown in Figure 5, suggesting that it corresponds to oxygen removal from either unexchanged $\mathrm{WO}_{3}$ (to form $\mathrm{WO}_{2}$ ) or from exchanged $\mathrm{WO}_{2}{ }^{+}$species. The amount of oxygen removed in this process corresponds to an $\mathrm{O} / \mathrm{W}$ ratio of $<0.15$. The reduction of bulk $\mathrm{WO}_{3}$ by $5 \% \mathrm{H}_{2}$ has been reported to occur via stepwise reduction: $\mathrm{WO}_{3} \rightarrow \mathrm{WO}_{2.9} \rightarrow$ $\mathrm{WO}_{2} \rightarrow \mathrm{W}$; the initial step occurs at $\sim 800 \mathrm{~K} .{ }^{26}$ Barton et al. have reported that this temperature increases with decreasing

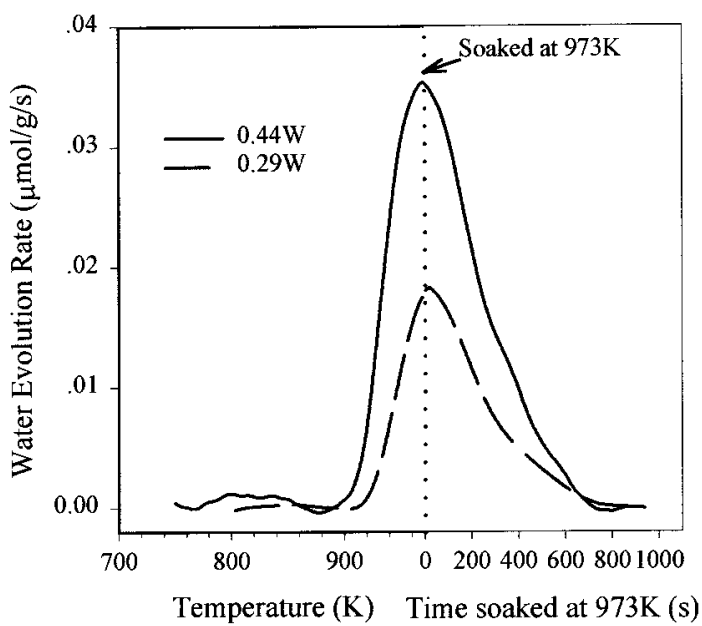

Figure 5. Water evolution rates during $\mathrm{D}_{2}-\mathrm{OH}$ exchange.
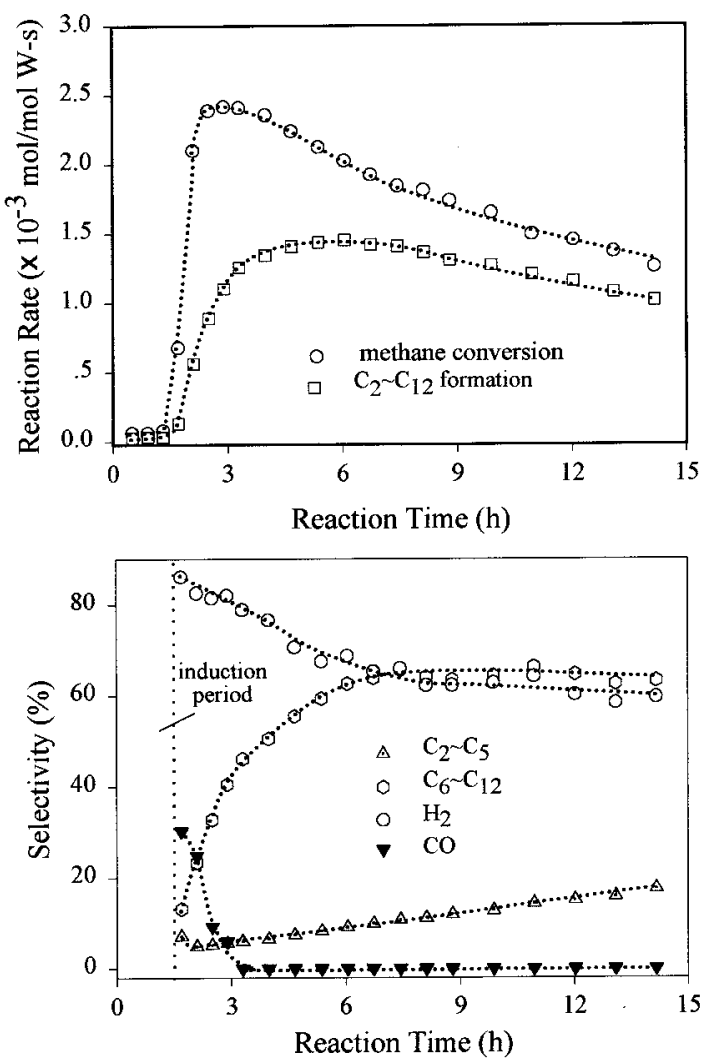

Figure 6. Catalytic performance for methane aromatization observed on $0.44 \mathrm{~W}$. ( $973 \mathrm{~K}, \mathrm{CH}_{4} / \mathrm{Ar}(1: 1) 12.5 \mathrm{~cm}^{3} / \mathrm{min}, 0.5 \mathrm{~g}$ of catalyst).

$\mathrm{WO}_{x}$ concentration on $\mathrm{ZrO}_{2}$ supports because of the lower reducibility of the smaller $\mathrm{WO}_{x}$ domains prevalent at low $\mathrm{W}$ surface densities on the support. ${ }^{27}$ These previous results are consistent with the assignment of the third $\mathrm{D}_{2}$ consumption peak to the reduction of highly dispersed but unexchanged $\mathrm{WO}_{x}$ species.

Figures 6 and 7 show the $\mathrm{CH}_{4}$ conversion rates and selectivities on $0.44 \mathrm{~W}$ and $0.29 \mathrm{~W}$ samples. Figure 8 shows similar data for a $3 \% \mathrm{Mo} / \mathrm{H}-\mathrm{ZSM} 5$ sample $\left(\mathrm{Mo} / \mathrm{Al}_{\mathrm{F}}=0.43\right.$; denoted as $0.43 \mathrm{Mo}$ ). Initial induction periods, during which methane conversion is very low and increases slowly with time, were observed on both W/H-ZSM5 catalysts. These induction periods are significantly longer $(2-4 \mathrm{~h})$ on W/H-ZSM5 than on Mo/ H-ZSM5 $(<0.4 \mathrm{~h}),{ }^{28}$ apparently as a result of the slower reduction and carburization of isolated $\mathrm{WO}_{x}$ species, compared with $\mathrm{MoO}_{x}$ dimers, during $\mathrm{CH}_{4}$ reactions. After this initial 

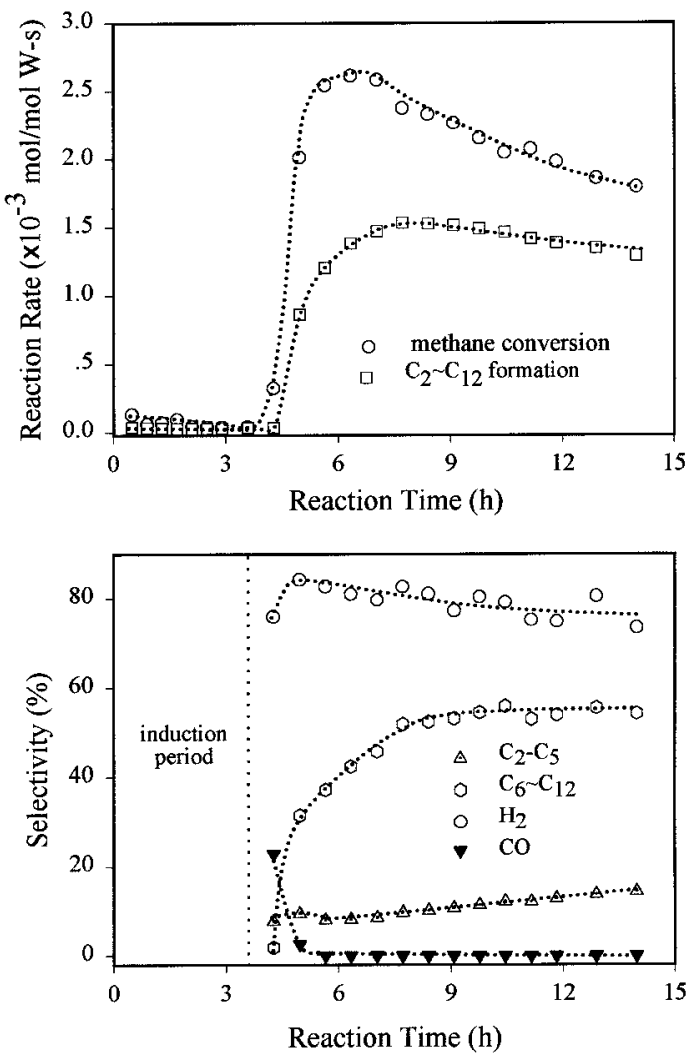

Figure 7. Catalytic performance of $0.29 \mathrm{~W}$ for methane reaction. ( 973 $\mathrm{K}, \mathrm{CH}_{4} / \mathrm{Ar}(1: 1) 12.5 \mathrm{~cm}^{3} / \mathrm{min}, 0.5 \mathrm{~g}$ of catalyst).
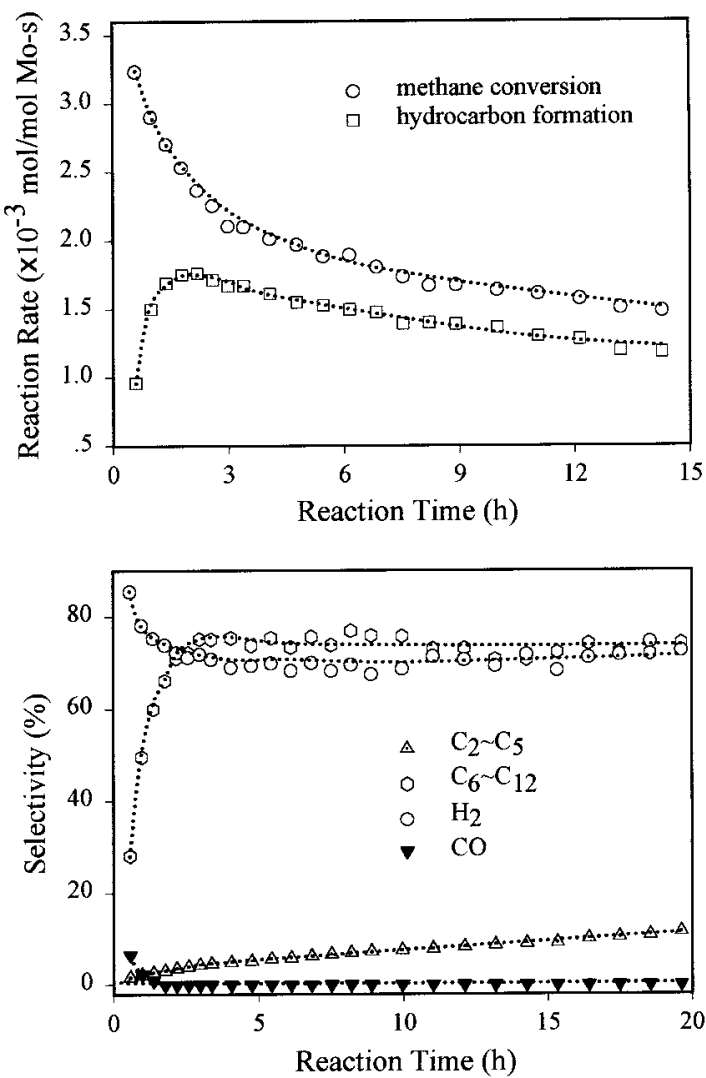

Figure 8. Catalytic performance of $0.43 \mathrm{Mo}(3 \mathrm{wt} \% \mathrm{Mo} / \mathrm{H}-\mathrm{ZSM}-5)$ for methane reaction. $\left(950 \mathrm{~K}, \mathrm{CH}_{4} / \mathrm{Ar}(1: 1) 12.5 \mathrm{~cm}^{3} / \mathrm{min}, 0.5 \mathrm{~g}\right.$ of catalyst).

induction period, $\mathrm{CH}_{4}$ conversion increased rapidly with time and $\mathrm{CO}$ simultaneously forms for a period of time on both Mo

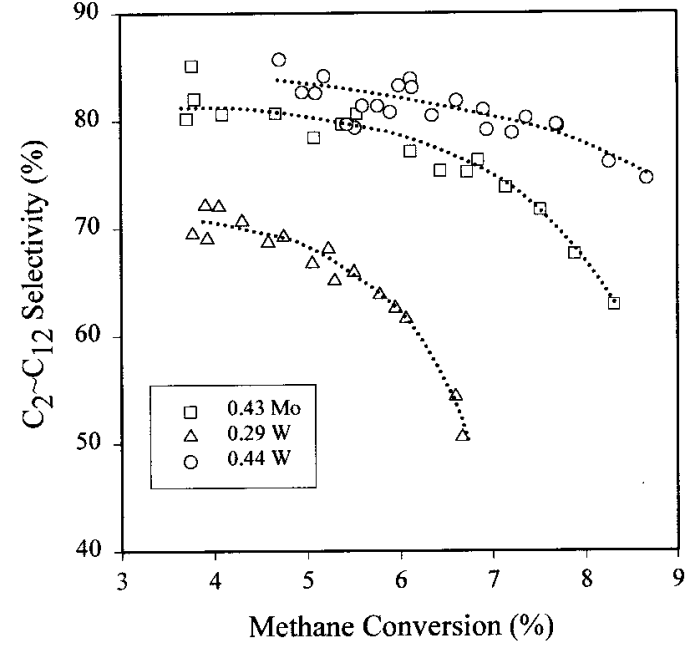

Figure 9. Effect of methane conversion on $\mathrm{C}_{2}-\mathrm{C}_{12}$ selectivity on $0.43 \mathrm{Mo}, 0.44 \mathrm{~W}$, and $0.29 \mathrm{~W}$.

and W samples; after this induction period, $\mathrm{CO}$ evolution stops and hydrocarbon formation rates reach steady-state values.

These results suggest that the autocatalytic formation of $\mathrm{WC}_{x}$ leads to active sites for $\mathrm{C}-\mathrm{H}$ activation using catalytically inactive $\mathrm{WO}_{x}$ exchanged species as precursors. Bulk $\mathrm{WO}_{3}$ carburization using $20 \% \mathrm{CH}_{4} / \mathrm{H}_{2}$ mixtures has been previously reported. ${ }^{29-31} \mathrm{WO}_{3}$ first reduces to $\mathrm{WO}_{3-x}$ by $\mathrm{H}_{2}$ at $\sim 700 \mathrm{~K}$, and $\mathrm{CH}_{4}$ then reacts with these partially reduced species at $\sim 900$ $\mathrm{K}$, with the concurrent evolution of $\mathrm{CO}, \mathrm{H}_{2}$, and $\mathrm{H}_{2} \mathrm{O}$. Carburization of bulk $\mathrm{WO}_{3}$ occurs in two distinct stages starting at $900 \mathrm{~K}$ and $973 \mathrm{~K}$, but it requires the initial involvement of $\mathrm{H}_{2}$ for the process to occur at these relatively low temperatures. The temperature required for carburization of exchanged $\mathrm{WO}_{x}$ species is apparently higher than for bulk $\mathrm{WO}_{3}$. This may reflect the lower reducibility of isolated species, which cannot nucleate a thermodynamically stable bulk carbide phase, or the initial absence of $\mathrm{H}_{2}$ during $\mathrm{CH}_{4}$ reactions, which requires that only $\mathrm{CH}_{4}$ be used in the initial reduction preceding carburization.

Maximum turnover rates (normalized per Mo or $\mathrm{W}$ atom) for hydrocarbon formation from $\mathrm{CH}_{4}$ are $1.76,1.25$, and 1.53 $\mathrm{mmol} /((\mathrm{g}$-atom $) \cdot \mathrm{s})$ on $0.43 \mathrm{Mo}, 0.44 \mathrm{~W}$, and $0.29 \mathrm{~W}$, respectively (950-973 K, $12.5 \mathrm{~cm}^{3} / \mathrm{min} \mathrm{CH}_{4} / \mathrm{Ar}(1: 1), 0.5 \mathrm{~g}$ of catalyst). Thus, turnover rates are very similar on $\mathrm{WC}_{x}$ and $\mathrm{MoC}_{x}$ species formed from their respective exchanged precursors during $\mathrm{CH}_{4}$ reactions. Selectivities to $\mathrm{C}_{2}-\mathrm{C}_{12}$ hydrocarbons are shown in Figure 9 as a function of $\mathrm{CH}_{4}$ conversion for $0.43 \mathrm{Mo}, 0.44 \mathrm{~W}$, and $0.29 \mathrm{~W}$ samples. At $5 \% \mathrm{CH}_{4}$ conversion, $\mathrm{C}_{2}-\mathrm{C}_{12}$ selectivities are $83.9,80.4$, and $68.4 \%$ on $0.43 \mathrm{Mo}, 0.44 \mathrm{~W}$, and $0.29 \mathrm{~W}$, respectively. Clearly, at similar levels of exchange $(0.43 \mathrm{Mo}$, $0.44 \mathrm{~W})$, rates $(1.76 \mathrm{mmol} /((\mathrm{g}$-atom $\mathrm{Mo}) \cdot \mathrm{s}, 1.49 \mathrm{mmol} /($ g-atom $\mathrm{W}) \cdot \mathrm{s})$ ) and selectivities $(83.9 \%, 80.4 \%)$ are almost identical on $\mathrm{W}$ and Mo samples.

Deactivation rates are also similar on these three catalysts. Figure 10 shows a semilogarithmic plot of the reaction rate on the three catalysts as a function of time on stream. The observed linear dependence is consistent with a first-order deactivation process, and the slope can be used to obtain the corresponding first-order deactivation rate constant. These rate constants are $0.0402,0.0307$, and $0.0341 \mathrm{~h}^{-1}$ on $0.43 \mathrm{Mo}, 0.44 \mathrm{~W}$, and $0.29 \mathrm{~W}$, respectively.

Prereduction of exchanged W/H-ZSM5 in $\mathrm{H}_{2}$ may shorten or remove the initial induction period observed during $\mathrm{CH}_{4}$ reactions. Figures 4 and 5 show that treatment in $\mathrm{D}_{2} / \mathrm{Ar}$ mixtures at $973 \mathrm{~K}$ for $0.5 \mathrm{~h}$ lead to partial reduction of exchanged tungsten 


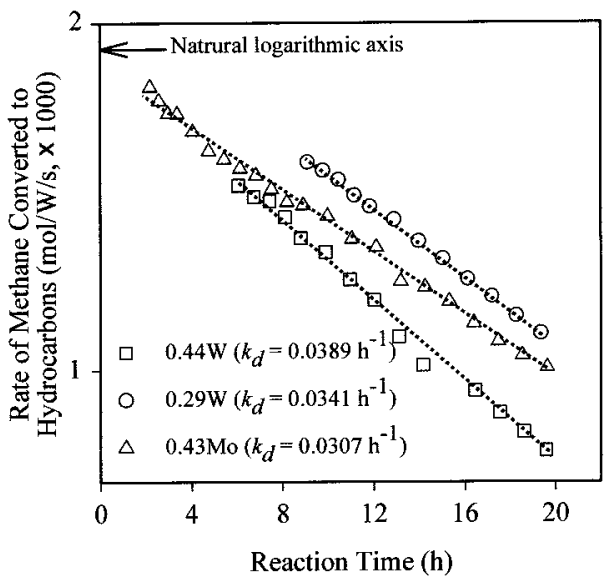

Figure 10. Catalyst deactivation rates for $0.44 \mathrm{~W}, 0.29 \mathrm{~W}$ and $0.43 \mathrm{Mo}$. ( $k_{d}$ is first-order deactivation constant).

species. $\mathrm{CH}_{4}$ reaction on $0.44 \mathrm{~W}$ treated in this manner did not show an induction period (Figure 11). $\mathrm{H}_{2}$ and $\mathrm{CO}$ evolved in a sharp peak during the first $100 \mathrm{~s}$ (Figure 11a), suggesting that prereduced $\mathrm{W}$ species carburize rapidly during the initial stages of methane reactions. The amount of $\mathrm{H}_{2}$ evolved during this initial peak was much greater than the amount of $\mathrm{CO}$ and $\mathrm{H}_{2} \mathrm{O}$ evolved $\left(\mathrm{H}_{2} /\left(\mathrm{CO}+\mathrm{H}_{2} \mathrm{O}\right)>10\right.$, in the initial $\left.100 \mathrm{~s}\right)$ or the amount expected for the observed formation of trace hydrocarbons, suggesting the significant retention of carbon within the W structures formed (Figure 11b).

These results lead us to a qualitative description of the reduction and carburization of $\mathrm{WO}_{x}$ species exchanged onto $\mathrm{H}$-ZSM5. $\mathrm{C}-\mathrm{H}$ bonds in $\mathrm{CH}_{4}$ are activated slowly until some of the $\mathrm{O}$ atoms in $\mathrm{WO}_{x}$ begin to be removed as $\mathrm{CO}_{x}$ and $\mathrm{H}_{2} \mathrm{O}$. As oxygen continues to be removed, $\mathrm{C}-\mathrm{H}$ bond activation becomes more facile and carbidic carbon starts to form more rapidly. The strong bond between carbidic carbon and tungsten provides a thermodynamic incentive for the aggregation of $\mathrm{W}$ species to form $\mathrm{W}-\mathrm{C}$ clusters. Carbidic carbon passivates the surface against further carbon deposition, but the surface retains some ability to activate $\mathrm{C}-\mathrm{H}$ bonds in $\mathrm{CH}_{4}$. The catalytic ability of $\mathrm{WC}_{x}$ sites in activation of $\mathrm{C}-\mathrm{H}$ bonds in alkanes is wellknown in the context of hydrogenation and dehydrogenation reactions. ${ }^{32,33}$

The proposed exchange and activation processes were examined using in-situ X-ray absorption measurements in order to probe the local structure and the oxidation state of $\mathrm{W}$ centers during dehydration and carburization. Figure 12 shows W L $_{\text {III }}$ absorption near-edge spectra (XANES) of $0.44 \mathrm{~W}$ after different treatments. All spectra display a strong peak at the absorption edge, sometimes referred to as the "white line", which results mainly from $2 p$ to $5 \mathrm{~d}$ bound state transitions. The intensity of this peak is usually indicative of the oxidation state of the absorber. ${ }^{34}$ Information about oxidation states is also contained in the edge position, which shifts to higher energies as core electrons are deshielded by the removal of some outer shell electrons upon oxidation. $\mathrm{L}_{\text {III }}$ edge shifts, however, tend to be very small. $\mathrm{W} \mathrm{L}_{\mathrm{III}}$ edges have been reported to shift to higher energies upon reduction from $\mathrm{WO}_{3}$ to $\mathrm{WO}_{2} ;{ }^{35}$ therefore, the absence of an absorption edge energy shift after treatment in $\mathrm{D}_{2} / \mathrm{Ar}$ does not exclude the possibility of $\mathrm{W}^{6+}$ to $\mathrm{W}^{5+}$ reduction. In contrast with the similarity between the XANES of dehydrated and $\mathrm{D}_{2}$ /Ar-treated catalyst precursors, a significant shift to lower binding energies and a decrease in the intensity of the white line are clearly observed after $\mathrm{CH}_{4}$ reactions, apparently as a result of the carburization of the $\mathrm{WO}_{x}$ precursors. The similarity between the $\mathrm{W} \mathrm{L}_{\mathrm{III}}$ XANES from this carburized
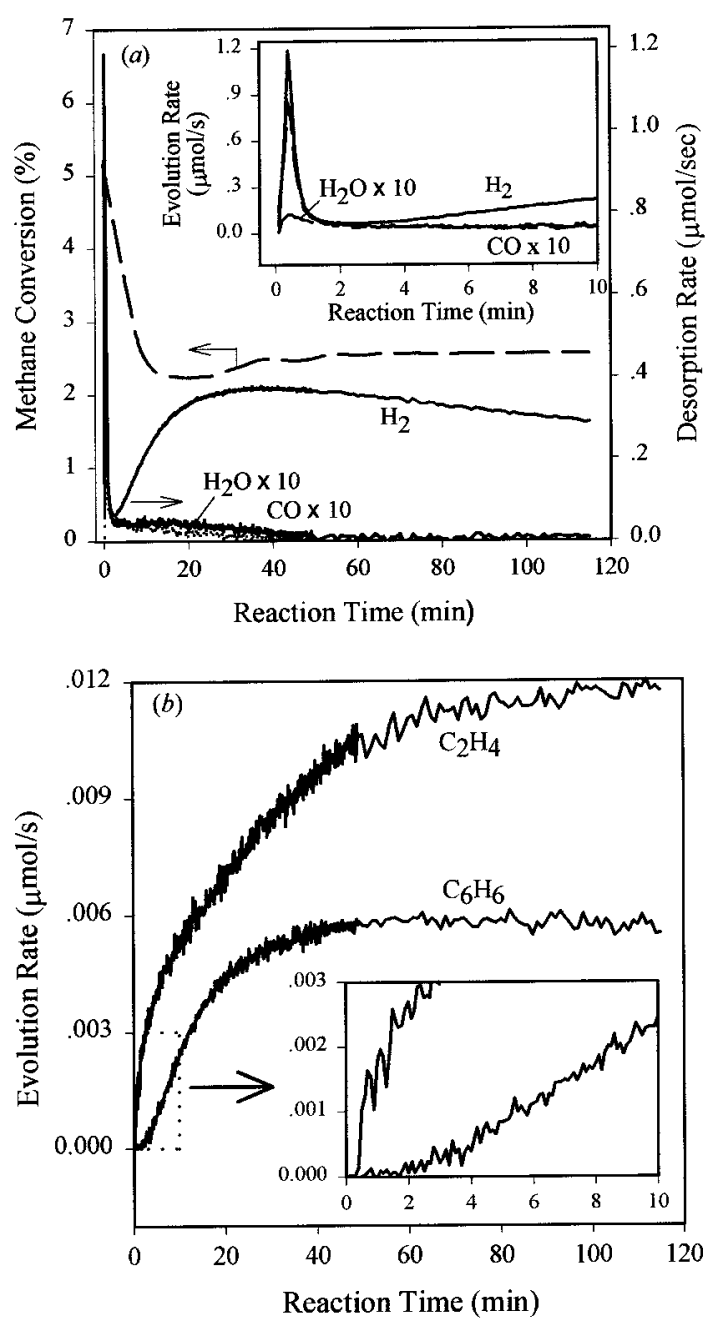

Figure 11. Isothermal transient reactions of methane on $0.44 \mathrm{~W}$. Methane conversion and product formation rates detected by mass spectrometry $\left[0.2 \mathrm{~g}\right.$ of $0.44 \mathrm{~W}$ was treated by $60 \mathrm{~cm}^{3} / \mathrm{min}$ at $973 \mathrm{~K}$ for $0.5 \mathrm{~h}$, and then the isothermal transient reaction of methane was carried out by switching the $\mathrm{D}_{2} / \mathrm{Ar}$ to $100 \mathrm{~cm}^{3} / \mathrm{min}^{\mathrm{CH}_{4}} / \mathrm{Ar} / \mathrm{He}$ (1:1:3); accurate determinations of the concentrations of species in the complex product mixture were achieved using frequent calibrations of the mass fragmentation patterns of individual compounds and matrix deconvolution methods that account for overlapping mass fragments arising from the product mixture].

sample and the WC standard sample (Figure 12) indicates that $\mathrm{W}$ has achieved an oxidation state similar to that of $\mathrm{W}$ atoms in WC. This is consistent with the reduction and $\mathrm{CH}_{4}$ reaction data described earlier (Figures 4, 5, and 10).

Experimental and simulated $k^{3}$-weighted tungsten radial distribution functions are shown in Figure 13 for the exchanged sample (after hydrolysis and dehydration) and for this sample after treatment in $\mathrm{D}_{2}$ at $973 \mathrm{~K}$ for $0.5 \mathrm{~h}$ and $\mathrm{CH}_{4}$ reaction at $973 \mathrm{~K}$ for $1 \mathrm{~h}$. The analysis of the radial structure functions was carried out on the dehydrated sample by using a $\mathrm{WO}_{3}$ cluster (Scheme 3) as the starting point for the structural refinement; the results are listed in Table 1. We found that one shell of oxygen neighbors was adequate to describe the major features in the fine structure. The interatomic distances for the first oxygen coordination sphere are shorter than in bulk $\mathrm{WO}_{3},{ }^{36}$ apparently because of the predominant presence of $\mathrm{W}=\mathrm{O}$ bonds in the prevalent isolated $\mathrm{WO}_{x}$ structures, compared with the longer $\mathrm{W}-\mathrm{O}-\mathrm{W}$ bonds in bulk $\mathrm{WO}_{3}$. The small coordination number for $\mathrm{W}$ neighbors in the second coordination shell in the exchanged $\mathrm{WO}_{x}$ precursors confirms the highly dispersed state of $\mathrm{W}^{6+}$ species in the exchanged sample. 


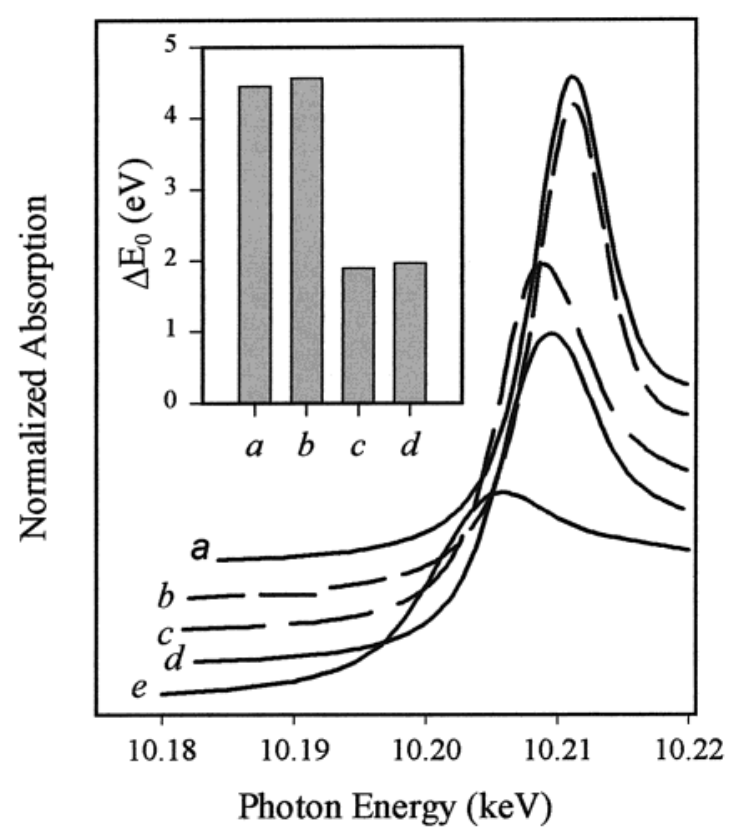

Figure 12. $\mathrm{W} \mathrm{L}_{\mathrm{III}}$ near-edge spectra for $0.44 \mathrm{~W}$ treated by different conditions: (a) dehydrated $\mathrm{WO}_{x} / \mathrm{H}-\mathrm{ZSM}-5$; (b) partially reduced $\mathrm{WO}_{x} /$ H-ZSM-5 (after $5 \% \mathrm{D}_{2} / \mathrm{Ar}$ treatment at $973 \mathrm{~K}$ for $0.5 \mathrm{~h}$ ); (c) W/HZSM-5 carburized for $1 \mathrm{~h}$ during methane reaction on partially reduced $\mathrm{WO}_{x} / \mathrm{H}-\mathrm{ZSM}$-5; (d) bulk WC; (e) W foil. Inset shows edge shift referenced to tungsten foil.

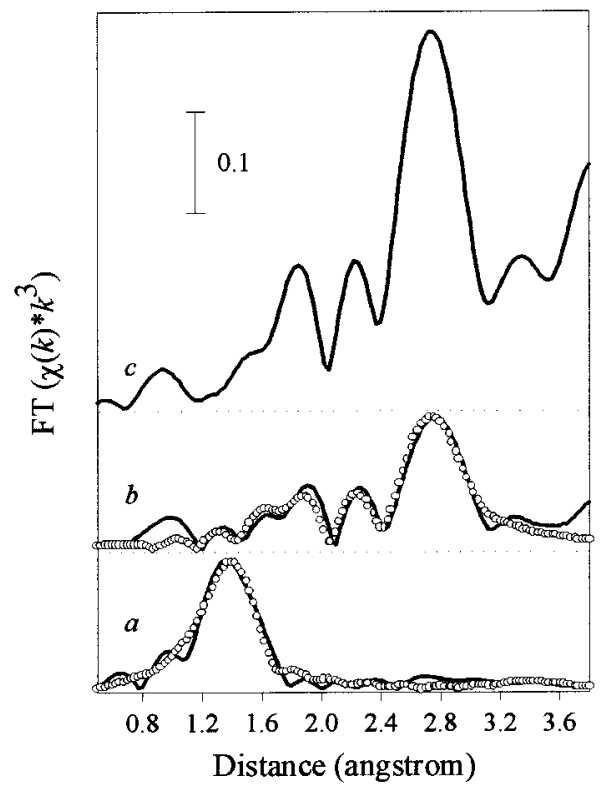

Figure 13. Tungsten radial distribution functions of bulk WC and $0.44 \mathrm{~W}$ treated under different conditions: (a) dehydrated $\mathrm{WO}_{x} / \mathrm{H}-\mathrm{ZSM}$ 5; (b) W/H-ZSM-5 carburized for $1 \mathrm{~h}$ during methane reaction on partially reduced $\mathrm{WO}_{x} / \mathrm{H}-\mathrm{ZSM}-5$; (c) bulk WC. Lines: Experimental data. Circles: Fitted results.

The structural refinement of a $0.44 \mathrm{~W}$ treated in $\mathrm{D}_{2} / \mathrm{Ar}$ and then used in $\mathrm{CH}_{4}$ reaction at $973 \mathrm{~K}$ for $1 \mathrm{~h}$ was carried out using the local structure of bulk $\mathrm{WC}$ as the starting point. $\mathrm{W}-\mathrm{C}$ and $\mathrm{W}-\mathrm{W}$ coordination numbers, interatomic distances, Debye-Waller factors, and energy shifts were allowed to vary in order to fit the experimental radial structure function. The structural parameters listed in Table 1 show that one $\mathrm{W}-\mathrm{C}$ and two $\mathrm{W}-\mathrm{W}$ shells were sufficient to describe the radial structure function of the $\mathrm{WC}_{x}$ species formed from exchanged $\mathrm{WO}_{x}$ during $\mathrm{CH}_{4}$ reactions. $\mathrm{W}-\mathrm{C}$ and $\mathrm{W}-\mathrm{W}$ interatomic distances ( 0.219 and $0.288 \mathrm{~nm}$, respectively) are similar to those in bulk

\section{SCHEME 3: W-O Model Clusters for EXAFS Fit of Dehydrated 0.44W}

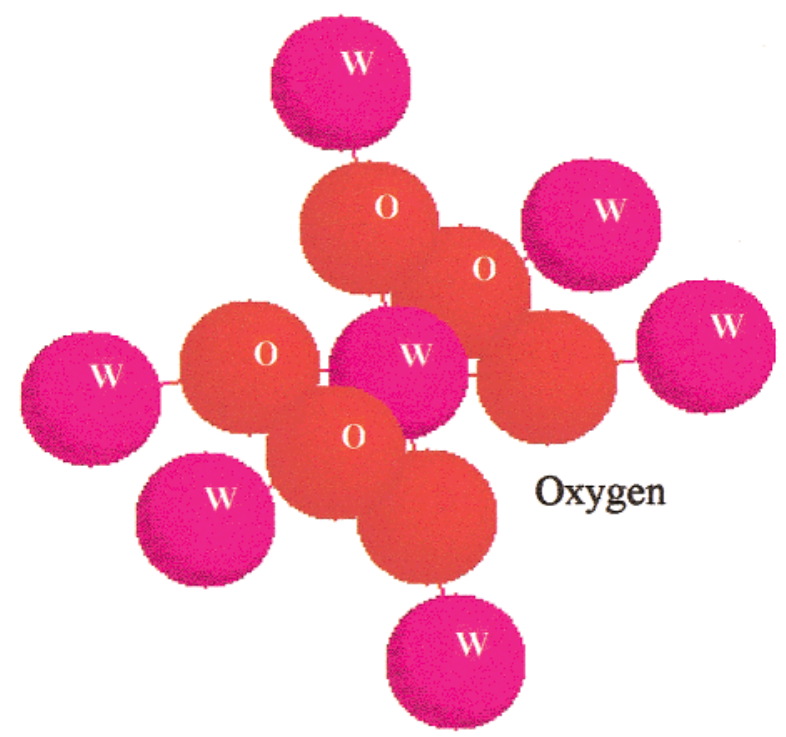

TABLE 1: Tungsten Structural Parameters in W/H-ZSM5 from Fits to W $\mathrm{L}_{\mathrm{III}}$ EXAFS $^{a}$

\begin{tabular}{ccccl}
\hline sample & shells & coordn no. & distance $(\AA)$ & $\sigma^{2} / \AA^{2}$ \\
\hline dehydrated W/H-ZSM5 & W-O & 4.7 & 1.765 & 0.007 \\
& W-W & 0.1 & 3.651 & 0 \\
carburized W/H-ZSM5 & W-C & 2.9 & 2.192 & 0.004 \\
& W-W & 1.1 & 2.769 & 0.0011 \\
& W-W & 2.4 & 2.882 & 0.00089
\end{tabular}

${ }^{a} \sigma^{2}$ : Debye-Waller factors. The starting points were FEFF8 simulations of $\mathrm{WO}_{3}{ }^{36}$ and WC. ${ }^{37}$ The amplitude reduction factor $\mathrm{So}^{2}$, calculated by FEFF8.0, had values of 0.95 and 0.90 for the $\mathrm{WO}_{3}$ and WC simulations, respectively. The $\sigma^{2}$ parameter was held fixed for the $\mathrm{W}-\mathrm{W}$ shells in the fits to the spectra before carburization, because they correlated strongly with the respective coordination numbers. Spectra of dehydrated W/H-ZSM5 were collected on hydrolyzed $0.44 \mathrm{~W}$, which was in-situ heated in $20 \% \mathrm{O}_{2} / \mathrm{He}$ to $973 \mathrm{~K}$ and held for $0.5 \mathrm{~h}$ after cooling to room temperature in He. After spectra collection for the dehydrated W/H-ZSM5 at room temperature, the sample was heated in $5 \% \mathrm{D}_{2} / \mathrm{Ar}$ to $973 \mathrm{~K}$ and held for $0.5 \mathrm{~h}$; then the $\mathrm{D}_{2} / \mathrm{Ar}$ was switched to $\mathrm{CH}_{4} / \mathrm{Ar}(1: 1)$ at that temperature for $1 \mathrm{~h}$. By cooling the sample to room temperature, the spectra for carburized W/H-ZSM5 were collected.

WC, ${ }^{37}$ suggesting that the local structure of the species formed during $\mathrm{CH}_{4}$ reactions resemble that in the $\mathrm{W}$ centers within bulk $\mathrm{WC}$. The other $\mathrm{W}-\mathrm{W}$ interatomic distance at $0.277 \mathrm{~nm}$ is similar to the first $\mathrm{W}$ neighbor distance in bulk body-centered cubic W metal $(0.274 \mathrm{~nm}) .{ }^{38} \mathrm{We}$ do not believe that this reflects the presence of $\mathrm{W}$ metal in these samples but only that the WC clusters formed within zeolite channels differ somewhat from bulk WC or that some clusters would be more accurately described by alternate $\mathrm{WC}_{x}$ phases with unusual stoichiometry and not available as crystalline structural standards. Even after $\mathrm{CH}_{4}$ reactions at $973 \mathrm{~K}$ for $1 \mathrm{~h}$, the $\mathrm{W}-\mathrm{W}$ coordination number is only $\sim 3$ (Table 1 ), suggesting that the $\mathrm{WC}_{x}$ clusters formed are indeed very small. The mechanism of the reductioncarburization of tungsten is shown in Scheme 4. The aggregation of tungsten requires some tungsten atoms to leave exchange sites in ZSM-5. The acid sites, removed by $\mathrm{W}$ exchange during the synthesis procedures, then become again available to catalyze the conversion of $\mathrm{C}_{2}+$ intermediates formed by cleavage of $\mathrm{C}-\mathrm{H}$ bonds in $\mathrm{CH}_{4}$ on the surface of $\mathrm{WC}_{\mathrm{x}}$ clusters.

Figure 14 shows a cluster with a diameter of $0.6 \mathrm{~nm}$ centered on the $\mathrm{W}$ site in $\mathrm{WC}$. The cluster contains nine $\mathrm{W}$ and six $\mathrm{C}$ atoms. The average $\mathrm{W}-\mathrm{C}$ and $\mathrm{W}-\mathrm{W}$ coordination numbers are 


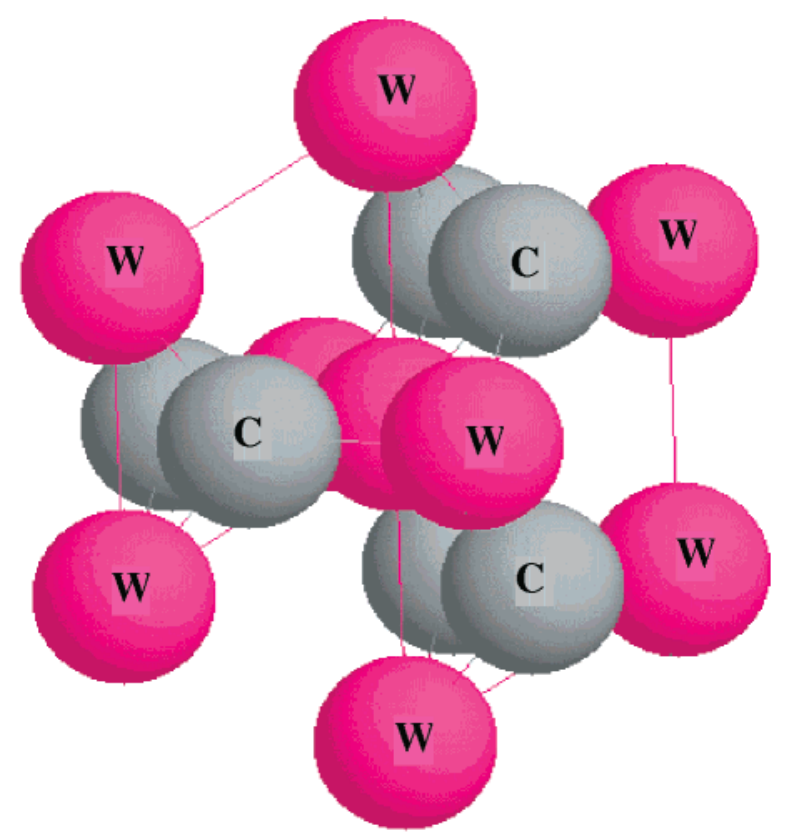

Figure 14. Cluster portraying a $3 \AA$ radius around the $\mathrm{W}$ site in WC. (It contains nine $\mathrm{W}$ atoms (dark) and six $\mathrm{C}$ atoms. The average first shell $\mathrm{W}-\mathrm{W}$ and $\mathrm{W}-\mathrm{C}$ coordination numbers for this cluster are both $\sim 2.5$.)

SCHEME 4: Reaction of Exchanged and Reduced $\mathrm{WO}_{x} /$ H-ZSM5 with Methane

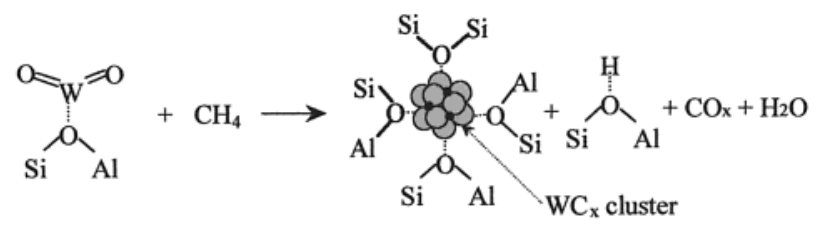

each about 2.5, slightly smaller than the experimental values of 2.9 and 3.5, respectively. These considerations and the XAS data reported here lead us to suggest that the size of the WC clusters is approximately equal to the structural channel diameter in H-ZSM5 $(0.55-0.57 \mathrm{~nm})$. This suggestion is consistent with the stable size and catalytic performance of these $\mathrm{WC}_{x}$ clusters during $\mathrm{CH}_{4}$ reactions for extended times $(\sim 20 \mathrm{~h})$, which would not be expected for WC clusters not stabilized by channel constraints.

The present investigation reveals striking similarities between W/H-ZSM-5 and Mo/H-ZSM5 in the structure of the active carbide species and in their catalytic behavior in $\mathrm{CH}_{4}$ reactions. The synthesis of exchanged $\mathrm{WO}_{x}$ precursors and their subsequent carburization during $\mathrm{CH}_{4}$ reactions are more difficult than for their Mo counterparts. This probably accounts for previous reports of the much inferior performance of W-based catalysts. As in the case of Mo/H-ZSM5, ${ }^{39}$ the carburization of exchanged $\mathrm{W}$ oxo precursors leads to the formation of the two active sites required for the bifunctional conversion of $\mathrm{CH}_{4}$ to alkenes and aromatics: $\mathrm{WC}_{x}$ and acidic $\mathrm{OH}$ species. $\mathrm{WC}_{x}$ species activate $\mathrm{C}-\mathrm{H}$ bonds in $\mathrm{CH}_{4}$ and form the initial $\mathrm{C}-\mathrm{C}$ bonds in products, and oligomerization, cracking, and cyclization of alkenes occur on Bronsted acid sites aided by $\mathrm{WC}_{x}$ species that remove $\mathrm{H}$-atoms formed in required dehydrogenation steps as $\mathrm{H}_{2}$.

\section{Conclusions}

Exchanged $\mathrm{WO}_{x} / \mathrm{H}-\mathrm{ZSM} 5$ samples were prepared by reaction of dehydrated $\mathrm{H}-\mathrm{ZSM} 5$ with $\mathrm{WCl}_{6}$ vapor at $673 \mathrm{~K}$. Exchanged $\mathrm{WCl}_{x}$ precursors were converted to $\mathrm{WO}_{x}$ species by hydrolysis in $\mathrm{H}_{2} \mathrm{O}$-containing streams. Isotopic exchange of residual $\mathrm{OH}$ groups with $\mathrm{D}_{2}$ showed that each exchanged $\mathrm{W}^{6+}$ replaces two protons to form $\left(\mathrm{WO}_{2}\right)^{2+}$ cations interacting with two exchange sites. Treatment in $\mathrm{H}_{2}$ (or $\mathrm{D}_{2}$ ) at temperatures up to $973 \mathrm{~K}$ led to the reduction of these $\left(\mathrm{WO}_{2}\right)^{2+}$ species to form $\left(\mathrm{WO}_{2}\right)^{+}$and restored one of the protons initially replaced during exchange. $\mathrm{CH}_{4}$ conversion turnover rates (per $\mathrm{W}$ ) and $\mathrm{C}_{2}-\mathrm{C}_{12}$ selectivities are very similar to those observed on Mo/H-ZSM5. As in the case of $\mathrm{MoO}_{x} / \mathrm{H}-\mathrm{ZSM} 5, \mathrm{WO}_{x} / \mathrm{H}-\mathrm{ZSM} 5$ precursors are initially inactive in $\mathrm{CH}_{4}$ reactions, but activate during reaction with the concurrent evolution of $\mathrm{CO}, \mathrm{H}_{2} \mathrm{O}$, and excess $\mathrm{H}_{2}$. XAS measurements showed that $\mathrm{WO}_{x} / \mathrm{H}-\mathrm{ZSM} 5$ precursors before methane reaction consisted of isolated $\mathrm{W}$ centers. The induction period observed during the early stages of $\mathrm{CH}_{4}$ reactions reflects the formation of $\mathrm{WC}_{x}$ clusters $(\sim 0.6 \mathrm{~nm}$ diameter $)$ from the initially exchanged and catalytically inactive $\left(\mathrm{WO}_{2}\right)^{2+}$ precursors. The coordination number of $\mathrm{W}$ centers in the activated catalysts is significantly lower than in bulk WC, as expected from the small size of the $\mathrm{WC}_{x}$ clusters. Perhaps coincidentally, the size of these clusters is similar to the diameter of the channels in the ZSM5 host.

Acknowledgment. We would like to acknowledge the financial support for this work from Mobil Corp. and from the Division of Fossil Energy of the U.S. Department of Energy (Contract DE-AC03-76SF00098). The authors also acknowledge valuable technical discussions with Dr. Daniel Driscoll of the U.S. Department of Energy. X-ray absorption data were collected at the Stanford Synchrotron Radiation Laboratory (SSRL), which is operated by the Department of Energy (DOE), Office of Basic Energy Sciences under Contract DE-ACO376SF00515. W.D. thanks Nanjing University for a leave of absence to carry out research at the University of California at Berkeley. The assistance of Dr. Shuibo Xie and Dr. Kaidong Chen in the measurement of the X-ray absorption spectra is gratefully acknowledged.

\section{References and Notes}

(1) Xu, Y. D.; Lin, L. W. Appl. Catal., A 1999, 188, 53.

(2) Wang, L. S.; Tao, L. X.; Xie, M. S.; Xu, G. F.; Huang, J. S.; and Xu, Y. D. Catal. Lett. 1993, 21, 35.

(3) (a) Weckhuysen, B. M.; Wang, D. J.; Rosynek, M. P.; Lunsford, J. H. J. Catal. 1998, 175, 338. (b) Weckhuysen, B. M.; Wang, D. J.; Rosynek, M. P.; Lunsford, J. H. J Catal. 1998, 175, 347.

(4) Zhang, C. L.; Li, S.; Yuan, Y.; Zhang, W.; Wu, T.; Lin, L. W. Catal. Lett. 1998, 56, 207.

(5) Liu, S. T.; Wang, L. S.; Ohnishi, R.; Ichikawa, M. J. Catal. 1999, 181,175 161.

(6) Shu, Y. Y.; Ma, D.; Bao, X. H.; Xu, Y. D. Catal. Lett. 2000, 66,

(7) Xu, Y. D.; Liu, S. T.; Wang, L. S.; Xie, M. S.; Guo, X. X. Catal. Lett. 1995, 30, 135.

(8) Shu, Y. Y.; Xu, Y. D.; Wong, S. T.; Wang, L. S.; Guo, X. X. J. Catal. 1997, 170, 11.

(9) (a) Xu, N.; Kan, Q. B.; Li, X. M.; Liu, Q. S.; Wu, T. H. Chem. J. Chin. Univ. 2000, 21 (6), 949. (b) Xu, N.; Kan, Q. B.; Zhang, J.; Li, X. M.; Ji, L.; Wu, T. H. Chem. J. Chin. Univ. 2000, 21 (7), 1113.

(10) (a) Wang, D. J.; Lunsford, J. H.; Rosynek, M. P. J. Catal. 1997, 169, 347. (b) Weckhuysen, B. M.; Rosynek, M. P.; Lunsford, J. H. Catal. Lett. 1998, 52, 31.

(11) Solymosi, F.; Szöke, A. Appl. Catal. A 1998, 166, 225. 43

(12) Solymosi, F.; Erdohelyi, A.; and Szöke, A. Catal. Lett. 1995, 32,

(13) Solymosi, F.; Szöke, A. Appl. Catal., A 1996, 142, 361.

(14) Solymosi, F.; Cserenyi, J.; Szöke, A.; Bansagi, T.; Oszko, A. J. Catal. 1997, 165, 150.

(15) Ledoux, M. J.; Cuong, P. H.; Guille, J.; Dunlop, H. J. Catal. 1992, $134,383$.

(16) Zeng, J. L.; Xiong, Z. T.; Zhang, H. B.; Lin, G. D.; Tsai, K. R. Catal. Lett. 1998, 53, 119.

(17) Borry, R. W.; Kim, Y. H.; Huffsmith, A.; Reimer, J. A.; Iglesia, E. J. Phys. Chem. B 1999, 103, 5787. 
(18) Kim, Y. H.; Borry, R. W.; Iglesia, E. Microporous Mesoporous Mater. 2000, 35, 495.

(19) Chen, H. Y.; Sachtler, W. M. H. Catal. Lett. 1998, 50, 125.

(20) CRC Handbook of Chemistry and Physics; CRC Press Inc.: Boca Raton, FL, 1994.

(21) Meitzner, G.; Iglesia, E. Catal. Today 1999, 53, 433.

(22) Barton, D. G.; Soled, S. L.; Meitzner, G. D.; Fuentes, G. A.; Iglesia, E. J. Catal. 1999, 181, 57.

(23) WinXAS97 is an XAS data analysis program for PCs running MSWindows by Thorsten Ressler (e-mail: t_ressler@compuserve.com; webpage: http://ourworld.compuserve.com/homepages/t_ressler).

(24) Rehr, J. J.; Albers, R. C.; Zabinsky, S. I.; Phys. Rev. Lett. 1992, $69,3397$.

(25) The code ATOMS is written by Bruce Ravel (e-mail: ravel@ u.washington.edu) to calculate coordination numbers and interatomic distances from compounds with known strunctures and all input for FEFF8.0.

(26) Vermaire, D. C.; van Berge, P. C. J. Catal. 1989, 116, 309.

(27) (a) Barton, D. G.; Shtein, M.; Wilson, R. D.; Soled, S. L.; Iglesia, E. J. Phys. Chem. B 1999, 103, 630. (b) Barton, D. G.; Soled, S. L.; Meitzner, D. G.; Fuentes, G. A.; Iglesia, E. J. Catal. 1999, 181, 57.

(28) Wang, D. J.; Lunsford, J. H.; Rosynek, M. P. Top. Catal. 1996, 3 ,
(29) Leclercq, G.; Kamal, M.; Giraudon, J. M.; Devassine, P.; Feigenbaum, L.; Leclercq, L.; Frennet, A.; Bastin, J. M.; Löfberg, A.; Decker, S.; Dufour, M. J. Catal. 1996, 158, 142

(30) Iglesia, E.; Ribeiro, F. H.; Boudart, M.; Baumgartner, J. E. Catal. Today, 1992, 15, 307.

(31) Iglesia, E.; Ribeiro, F. H.; Boudart, M.; Baumgartner, J. E. J. Catal. 1991, 131, 137.

(32) Oyama, S. T. Catal. Today 1992, 15, 179.

(33) Keller, V.; Wehrer P.; Garin, F.; Ducros, R.; Maire, G. J. Catal. 1995, 153,9 .

(34) Sinfelt, J. H.; Meitzner, G. D. Acc. Chem. Res. 1993, 26, 1.

(35) Khyzhun, O. Y. J. J. Alloys Compd. 2000, 305, 1.

(36) (a) Gerand, B.; Nowogrocki, G.; Guenot, J.; Figlars, M. J. Solid State Chem. 1979, 29, 429. (b) Palmer, D. J.; Dickens, P. G. Acta Crystallogr. B 1979, 35, 2199.

(37) Rieck, G. D. Tungsten and Its Compounds; Pergamon: New York, 1967.

(38) Slater, J. C. Symmetry and Energy Bands in Crystals; Dover: New York, 1972; p 331.

(39) Ding, W. P.; Li, S.; Meitzner, G. D.; Iglesia, E. J. Phys. Chem. B 2001, 105, 506 